\title{
Corrosion Behavior of AISI 304 Stainless Steel in Aggressive Chloride Environment
}

Viera Zatkalíková, Lenka Markovičová, Tatiana Liptáková, Alan Vaško

Faculty of Mechanical Engineering, University of Žilina, Univerzitná 1, 01026 Žilina, Slovakia. E-mail: viera.zatkalikova@fstroj.uniza.sk, lenka.markovicova@fstroj.uniza.sk

Cr-Ni stainless steels are commonly used for construction of various equipments exposed to halides containing media, which can act aggressively and cause a serious local corrosion damage of these materials. This article focuses on the resistence of AISI 304 stainless steel to the pitting corrosion in $1 \mathrm{M}$ acidified chloride solution represented by mixture $0.9 \mathrm{M} \mathrm{NaCl}+0.1 \mathrm{M} \mathrm{HCl}$, at the ambient temperature of $22 \pm 3{ }^{\circ} \mathrm{C}$. An evaluation of the pitting corrosion resistance was based on the cyclic potentiodynamic polarization tests performed on three types of steel surfaces: "as received", electropolished and ground + electropolished surfaces. The pitting potentials were determined and compared. Pitted surfaces after potentiodynamic polarization tests were observed by the optical microscope.

Keywords: Cr-Ni stainless steel, Pitting corrosion, Electropolishing, Cyclic potentiodynamic test

\section{Acknowledgement}

The research was supported partially by Scientific Grant Agency of Ministry of Education, Science and Sport of Slovak Republic and Slovak Academy of Sciences, grant VEGA No. 1/0683/15 and grant KEGA No. 049ŽU-4/2017.

\section{References}

[1] SZKLARSKA - SMIALOWSKA, Z. (2005). Pitting and crevice corrosion, pp. 12 - 25, NACE International, Houston, Texas.

[2] LIPTÁKOVÁ, T., ALASKARI, A., HALAMOVÁ, M. (3012). Surface treatment of the AISI 316L after welding and study of corrosion behaviour. Periodica Polytechnica Transportation Engineering, Vol. 41, No. 2, pp. 143147.

[3] ZATKALÍKOVÁ, V., MARKOVIČOVÁ, L., BELAN, J., LIPTÁKOVÁ, T. (2014). Variability of local corrosion attack morphology of AISI 316ti stainless steel in aggressive chloride environment. Manufacturing Technology, Vol. 14, No 3, pp. 493-497.

[4] LIPIŃSKI, T., (2016). Corrosion resistance of 1.4362 steel in boiling 65\% nitric acid. Manufacturing Technology, Vol. 16, No. 5, pp. 1004-1009.

[5] UHRÍČIK, M, ORAVCOVÁ, M., PALČEK, P., SAPIETA, M., CHALUPOVÁ, M. (2016). The stress detection and the fatigue lifetime of stainless steel AISI 316L during three-point bending cyclic loading (Conference Paper), EAN 2016 - 54th International Conference on Experimental Stress Analysis.

[6] ZÁVODSKÁ, D., GUAGLIANO, M., BOKŮVKA, O., TRŠKO, L. (2016). Effect of Shot Peening on the Fatigue Properties of 40NiCrMo7 steel. Manufacturing Technology, Vol. 16, No. 1, pp. 299 - 304.

[7] HONG, T., NAGUMO, M., (1997). Effect of surface roughness on early stages of pitting corrosion of Type 301 stainless steel. Corros. Sci. Vol. 39, No. 9, pp. 1665-1672.

[8] SASAKI, K., BURSTEIN, G. T. (1996). The generation of surface roughness during slurry erosion-corrosion and its effect on the pitting potential. Corros. Sci. Vol. 38, No. 12, pp. 2111-2120.

[9] LEE, S. J., LAI, J.J. (2003). The effects of electropolishing (EP) proces parameters on corrosion resistence of $316 \mathrm{~L}$ stainless steel. Journal of Material Processing Technology 140pp. 206-210.

[10] NÚÑEZ, P. J., GARCÍA-PLAZA, E., HERNANDO, M., TRUJILLO, (2013). Characterization of Surface Finish of Electropolished Stainless steel AISI 316L with Varying Electrolyte Concentrations. Procedia Engineering 63, pp. 771-778.

[11] www.italinox.sk 12.4. 2017.

[12] ORAVCOVÁ, M., PALČEK, P., ZATKALIKOVÁ, V., TAŃSKI, T., KRÓL, M. (2017 ). Surface treatment and corrosion behaviour of austenitic stainless steel biomaterial. IOP Conference Series: Materials Science and Engineering, Vol. 175, No. 1.

[13] HASHIMOTO, K., ASAMI, K., KAWASHIMA, A., HABAZAKI, H., AKIYAMA, E. (2007). The role of Corosion-resistant alloying Elements in Passivity. Corros. Sci., Vol. 49, No. 1, pp. 42-52.

[14] GHANAVATI, S., SHISHESAZ, M. R., FARZAM, M., DANAEE, I. (2015). Effects of Surface Treatment on Corrosion Resistance of 304L and 316L Stainless Steel Implants in Hank's Solution. Iranian Journal of Oil \& Gas Science and Technology, Vol. 5, No. 1, pp. 65-72. 